\title{
21. PORE WATERS FROM SERPENTINITE SEAMOUNTS IN THE MARIANA AND IZU-BONIN FOREARCS, LEG 125: EVIDENCE FOR VOLATILES FROM THE SUBDUCTING SLAB ${ }^{1}$
}

\author{
Michael J. Mottl ${ }^{2}$
}

\begin{abstract}
Sediment pore fluids sampled by drilling in subduction zones are commonly depleted in chloride relative to seawater and highly enriched in methane. These features have been attributed to processes within the accretionary prism of sediment that is typical of most subduction zones. Sites 778 through 780 in the Mariana forearc yielded low-chlorinity pore fluids rich in methane, ethane, and propane from a subduction zone setting that lacks an accretionary prism. They were drilled on the flanks and summit of Conical Seamount, an active serpentine mud volcano located $80 \mathrm{~km}$ behind the Mariana Trench and $120 \mathrm{~km}$ in front of the island arc. Alvin dives on this summit in 1987 found chimneys made of aragonite, calcite, and amorphous $\mathrm{Mg}$-silicate from which cold water was seeping. During drilling at the summit Site 780 we recovered these fluids from serpentine silts at depths up to 130 mbsf and demonstrated that the fluids are upwelling through the seamount at velocities greater than a few millimeters per year. The fluids have less than one-half the chloride and bromide of seawater, $\mathrm{pH}$ up to 12.6 , methane up to $37 \mathrm{mmol} / \mathrm{kg}$ along with ethane and propane, $\mathrm{H}_{2} \mathrm{~S}$ up to $2 \mathrm{mmol} / \mathrm{kg}$, and ammonia up to $270 \mu \mathrm{mol} / \mathrm{kg}$. Relative to seawater, they are enriched in alkalinity $(\times 26)$, sulfate $(\times 1.7), \mathrm{K}(\times 1.5), \mathrm{Rb}(\times 5.6)$, and $\mathrm{B}(\times 10)$. They are highly depleted in $\mathrm{Li}, \mathrm{Mg}, \mathrm{Ca}, \mathrm{Sr}$, and ${ }^{34} \mathrm{~S}$, and have low concentrations of $\mathrm{Si}, \mathrm{Ba}$, and $\mathrm{Mn}$. Although they are also depleted in $\mathrm{Na}$, their $\mathrm{Na} / \mathrm{Cl}$ ratio increases to nearly twice that in seawater.

These pore fluids from the summit of Conical Seamount contrast greatly with those recovered from Sites 783 and 784 on Torishima Seamount, an inactive serpentinite seamount in the Izu-Bonin forearc. The Torishima pore fluids were produced by the reaction of seawater with harzburgite at low temperatures. They have $\mathrm{pH}$ up to 10 , very low $\mathrm{Si}, \mathrm{Mn}$, and methane, and no ethane or propane. Relative to seawater, they have low alkalinity, sulfate, $\mathrm{Mg}, \mathrm{K}$, and $\mathrm{B}$; slightly lower $\mathrm{Li}$ and $\mathrm{Rb}$; little-changed chloride, $\mathrm{Br}, \mathrm{Na}$, and $\mathrm{Na} / \mathrm{Cl}$; and high $\mathrm{Ca}, \mathrm{Sr}, \mathrm{Ba}$, and ${ }^{34} \mathrm{~S}$. Pore waters from Sites 778 and 779 on the flanks of Conical Seamount are complex mixtures of these two types of fluids.

The absence of an accretionary prism in the Mariana forearc severely constrains the origin of the fluids upwelling through Conical Seamount. Their freshening relative to seawater does not result from uptake of chloride into solids during serpentinization, but it requires instead a source of $\mathrm{H}_{2} \mathrm{O}$ deeper than was drilled. Whereas the presence of gas hydrates cannot be excluded, there is no direct evidence of them, and they probably are not a major source of $\mathrm{H}_{2} \mathrm{O}$. The fluids at Conical Seamount probably originate at the top of the downgoing slab, $30 \mathrm{~km}$ below the seafloor, by heating of the sediments and basalt of the subducted oceanic crust. The water driven off serpentinizes the overlying mantle wedge. Serpentinite seamounts subsequently act as conduits through which $\mathrm{H}_{2} \mathrm{O}, \mathrm{CO}_{2}$, hydrocarbons, and sulfur pass from the slab into the oceans.
\end{abstract}

\section{INTRODUCTION}

Because of their potential role in transferring material from the surface of the earth back into its deep interior, processes of mass transfer in subduction zones are of great interest to geochemists. While the bulk of the downgoing lithospheric plate reenters the asthenosphere during subduction, scientists have long suspected that some material, particularly from the upper part of the oceanic crust, makes its way back to the surface via processes that are poorly known at present (Peacock, 1990). To identify and quantify the various processes that occur in subduction zones, scientists of the Deep Sea Drilling Project (DSDP) and Ocean Drilling Program (ODP) have drilled in several such zones, including the Japan Trench during DSDP Leg 57, the Middle America Trench off Mexico during DSDP Leg 66 and off Guatemala during Legs 67 and 84, the Northern Barbados Ridge during ODP Leg 110, and the Peru continental margin during Leg 112.

Pore waters collected from sediments in all of these subduction zones share an unusual feature, compared with waters from marine sediments elsewhere: highly variable chlorinity. Whereas large increases in chlorinity relative to seawater were found in some of these subduction zones, large decreases of one-quarter to one-half occurred in all of them, i.e., the pore waters commonly are much fresher than seawater. As the chlorinity of the pore waters was typically still decreasing with depth at the maximum depth drilled, the ultimate origin of the freshened water has remained speculative. This freshen-

'Fryer, P., Pearce, J. A., Stokking, L. B., et al., 1992. Proc, ODP, Sci. Results, 125: College Station, TX (Ocean Drilling Program).

${ }^{2}$ Department of Oceanography, University of Hawaii, Honolulu, HI 96822, U.S.A. ing has been attributed to the presence of fossil freshwater aquifers, the formation and melting of hydrocarbon gas hydrates, membrane filtration by clays, removal of interlayer water from clay minerals and opal, and higher temperature removal of structural water from hydrous alteration minerals. Most of these explanations require the presence of a thick sedimentary sequence to be viable, and such a sequence is indeed present at all of the above subduction zones in the form of an accretionary prism, accumulated by offscraping of sediment from the top of the downgoing plate and by volcanism and erosion in the associated volcanic arc.

Here we report the discovery of greatly freshened pore waters of unusual composition from a subduction zone that lacks an accretionary prism of sediment. These pore waters were collected during Leg 125 from Conical Seamount, an active serpentine "mud volcano" in the Mariana forearc (Fig. 1). The Mariana subduction zone is nonaccretionary, and tectonic erosion has been suggested to occur in the forearc. The pore waters were sampled from silts that consist almost entirely of serpentine and contain suspended clasts of serpentinized harzburgite. Geologic evidence indicates that Conical Seamount is an active mud volcano, with a central conduit of low-density serpentine that rises buoyantly through the crust and produces periodic, unconsolidated, cold serpentine mud and debris flows ("sedimentary serpentinite") that move downslope to form the flanks of the seamount (Fryer et al., 1990). The low-chlorinity pore waters are flowing upward through the core of the seamount and exit at the summit to form chimneys of $\mathrm{Ca}$-carbonate and amorphous $\mathrm{Mg}$-silicate (Haggerty, 1987a; Fryer et al., 1990). We postulate that these freshened waters originate by dehydration at the top of the subducting slab $30 \mathrm{~km}$ below the seafloor. As they rise, they serpentinize the overlying mantle wedge and eventually mix at shallow levels with 


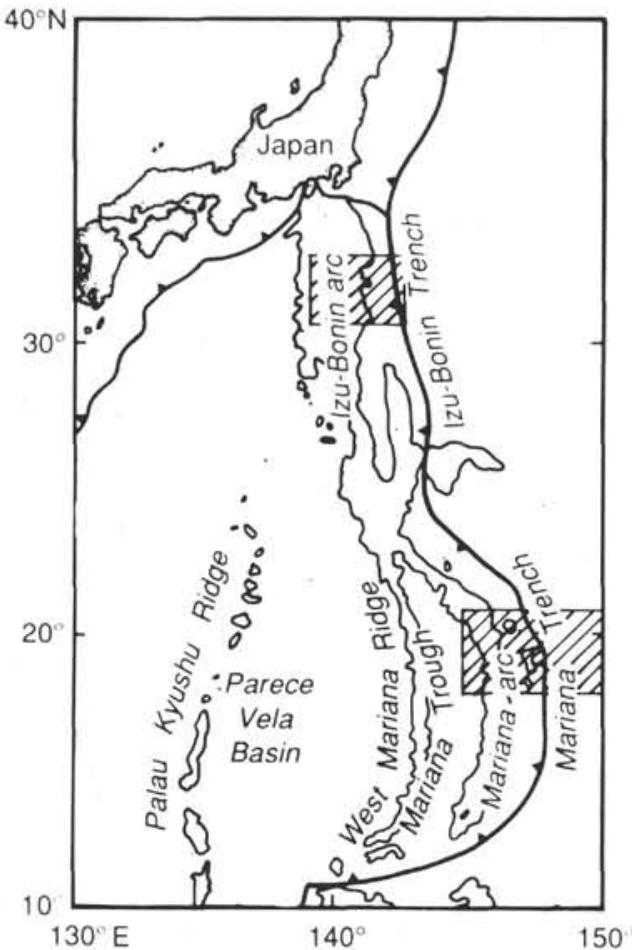

Figure 1. Active plate boundaries in the Philippine Sea region. Barbed lines locate subduction zones. Basins and ridges are outlined by the $4-\mathrm{km}$ bathymetric contour, except for the Izu-Bonin, West Mariana, and Mariana arcs, which are outlined by the $3-\mathrm{km}$ contour. Hachured boxes show locations of Figures 2 and 3 . seawater that has reacted with ultramafic rock. To identify and characterize the reacted fluids from these two sources, we present evidence from pore waters that were collected by drilling on a second serpentinite seamount, Torishima Seamount in the Izu-Bonin forearc, that shows no sign of activity and contains only seawater-derived fluids that have reacted with peridotite.

\section{GEOLOGIC SETTING}

Sites 778 through 780 were drilled on Conical Seamount, which lies in a broad zone of forearc seamounts situated along the Mariana outer-arc high between 50 and $120 \mathrm{~km}$ behind the Mariana Trench axis. Conical Seamount is $20 \mathrm{~km}$ in diameter, $1500 \mathrm{~m}$ high, and nearly circular in plan view (Fig. 2). It is located about $80 \mathrm{~km}$ behind the trench axis and $120 \mathrm{~km}$ in front of the active island arc. Sites 778 and 779 were drilled on the south and southeast flanks at 3914 and 3947 mbsl, respectively. Site 780 consists of four holes drilled at the summit at 3083 to $3094 \mathrm{mbsl}, 4.6 \mathrm{~km}$ from the flank sites. Drilling at all three sites penetrated mainly unconsolidated clay-to sand-sized serpentine with suspended clasts of variously serpentinized harzburgite, dunite, and scarce metabasalt. Clasts vary in size from sand to boulders. The serpentine matrix material is sheared and foliated at the flank sites, indicating that they penetrated sedimentary serpentinite flows, but not at the summit site.

Sites 783 and 784 were drilled on Torishima Seamount on the north and west flanks at 4649 and $4901 \mathrm{mbsl}$, respectively. Torishima Seamount is $20 \mathrm{~km}$ wide, more than $600 \mathrm{~m}$ high, and semicircular in plan view, perched as it is about halfway up the flank of the outer-arc high (Fig. 3). The seamount is located about $30 \mathrm{~km}$ behind the axis of the Izu-Bonin Trench and $170 \mathrm{~km}$ in front of the island arc. The summit lies above 4100 mbsl. Drilling at both sites penetrated a glass-rich layer of silty clay to claystone and then bottomed in phacoidal sheared serpentine silt containing clasts of serpentinized

$0 \quad 10 \mathrm{KM}$

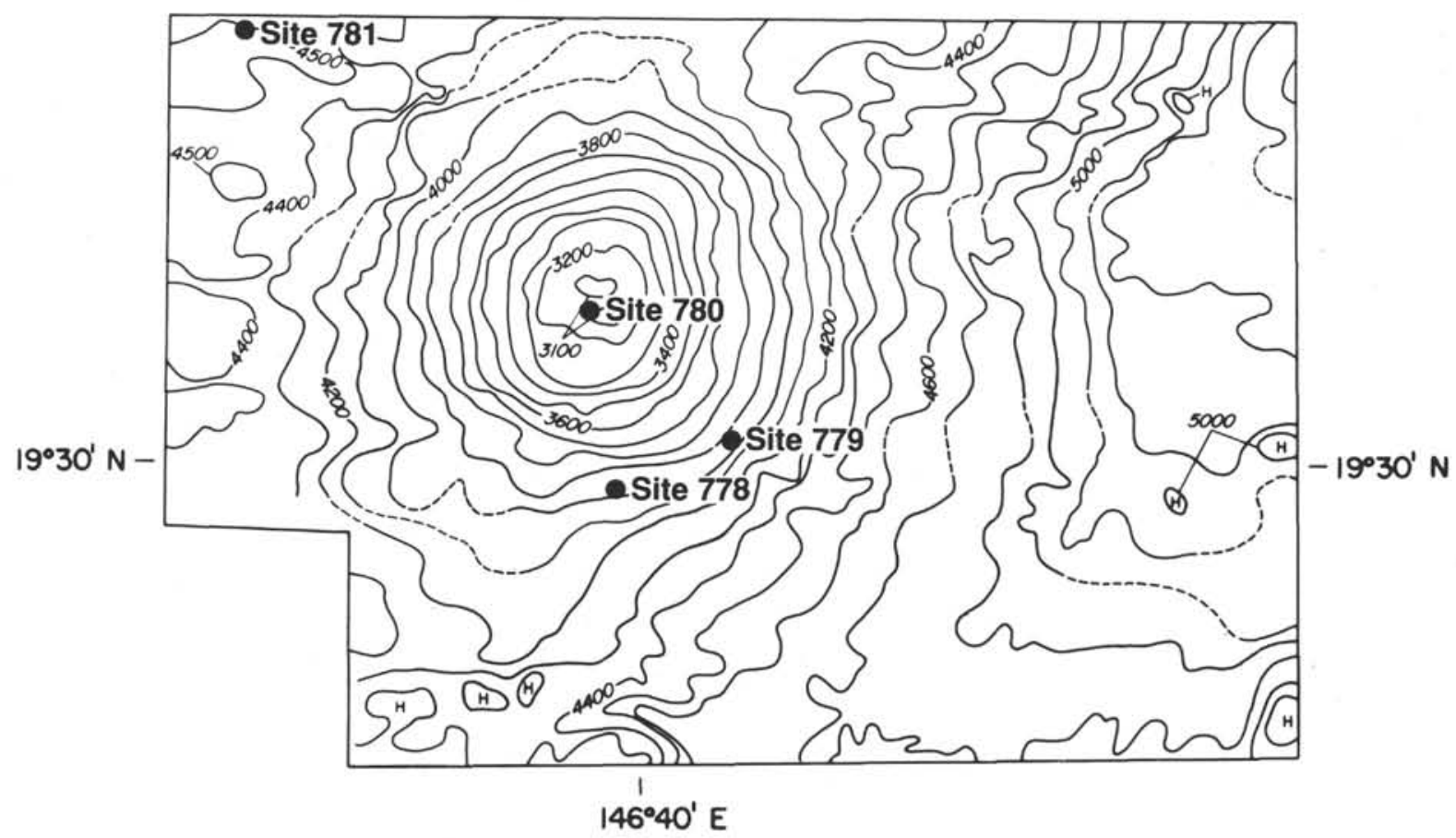

Figure 2. Bathymetric sketch of Conical Seamount in the Mariana forearc showing the locations of Sites 778 through 781 . Bathymetry in meters. 


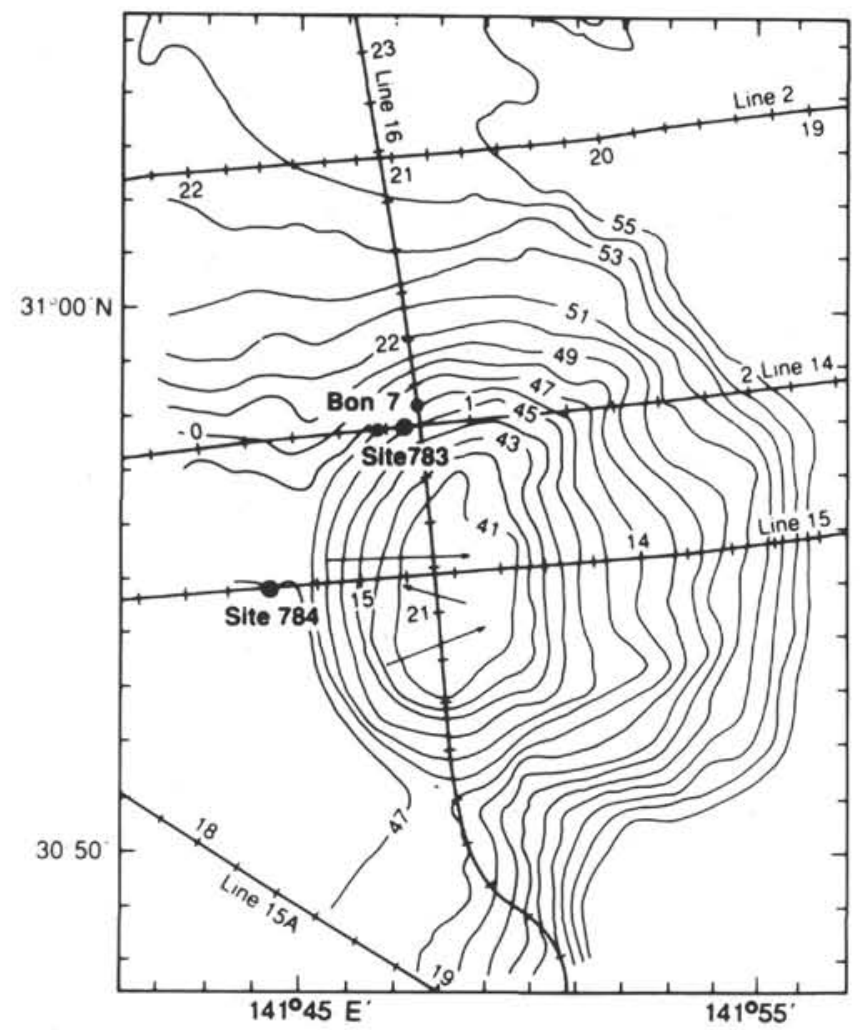

Figure 3. Bathymetric sketch of Torishima Forearc Seamount in the Izu-Bonin forearc showing the locations of Sites 783 and 784. Bathymetry in meters.

harzburgite, dunite, and scarce metabasalt. The transition from claystone to sedimentary serpentinite occurs abruptly at Site 783, at 120 mbsf, and more gradually at Site 784 , by interlayering between 303 and $321 \mathrm{mbsf}$.

\section{COMPOSITION OF PORE WATERS FROM CONICAL AND TORISHIMA SEAMOUNTS}

The composition of pore waters from all five sites drilled on both serpentinite seamounts is plotted vs. depth in Figures 4 through 9. These data are tabulated and the sampling and analytical methods are given by the Shipboard Scientific Party (1990a-f) and by Mottl and Alt (this volume).

Pore waters from Site 780 on the summit of Conical Seamount are among the most unusual ever sampled in the deep sea. They have probably the highest $\mathrm{pH}$ ever measured in a deep-sea sediment, up to 12.6. They have lower chlorinity than at any other site drilled in a subduction zone, up to $57 \%$ lower than that in seawater. They show a large increase in alkalinity with depth, to 26 times the value in seawater, and are highly enriched in the light hydrocarbons methane, ethane, and propane. The sulfate concentration increases to 1.7 times that in seawater, and one sample from $2.7 \mathrm{mbsf}$ in Hole 780D yielded $2 \mathrm{mmol} / \mathrm{kg} \mathrm{H}_{2} \mathrm{~S} .8^{34} \mathrm{SO}_{4}$ decreases from the seawater value of +20.5 to about $13.5 \%$ as the sulfate concentration increases (Mottl and Alt, this volume). Relative to seawater, the pore waters at Conical Seamount summit are also enriched in ammonia, $\mathrm{K}(\times 1.5), \mathrm{Rb}(\times 5.6)$, and $\mathrm{B}(\times 10)$. They are highly depleted in $\mathrm{Li}$, $\mathrm{Mg}, \mathrm{Ca}, \mathrm{Sr}$, and $\mathrm{Br}$ and have low concentrations of $\mathrm{Si}, \mathrm{Ba}$, and $\mathrm{Mn}$. They are also depleted in $\mathrm{Na}$, and their $\mathrm{Na} / \mathrm{Cl}$ ratio increases to nearly twice that in seawater. All of these changes take place near the seafloor, in the upper few meters of the serpentine silt, and most persist to at least 130 mbsf, the maximum depth sampled.

Pore waters from serpentine silt at Sites 783 and 784 on Torishima Seamount contrast greatly with those from the summit of Conical
Seamount (Table 1). The $\mathrm{pH}$ elevation from to 9 to 10 is not nearly as high as that at the summit of Conical Seamount. There is no freshening relative to seawater: chlorinity and $\mathrm{Br}$ are nearly constant with depth. Among the hydrocarbons, only methane is detectable, at very low concentrations (less than $3 \mathrm{mmol} / \mathrm{kg}$ ). Many species that are elevated relative to seawater at Conical Seamount summit are depressed in the Torishima serpentine, including alkalinity, sulfate, $\mathrm{K}$, and $\mathrm{B}$. Conversely, species that are depressed at Conical are elevated at Torishima, including $\mathrm{Ca}, \mathrm{Sr}, \mathrm{Ba}$, and $\delta^{34} \mathrm{SO}_{4}$. Species that are greatly changed at Conical, but not at Torishima, include $\mathrm{Na}$ (and $\mathrm{Na} / \mathrm{Cl}$ ), $\mathrm{Rb}$, and, relative to concentrations in pore waters of the overlying claystone, $\mathrm{Li}$ and ammonia, as well as $\mathrm{Cl}$ and $\mathrm{Br}$. The only elements that behave similarly at the two localities are $\mathrm{Si}, \mathrm{Mg}$, and $\mathrm{Mn}$, all of which are present at very low concentrations. Pore waters from the flanks of Conical Seamount at Sites 778 and 779 are generally intermediate in composition between the summit Site 780 and the Torishima Sites 783 and 784 . Site 778 resembles the Torishima sites for all species in Figures 4 through 9 except for lower chlorinity and higher $\mathrm{Si}, \mathrm{Br}, \mathrm{Na} / \mathrm{Cl}$, and $\mathrm{Sr}$. Site 779 is intermediate for all species, except that it has the lowest ammonia and the highest $\mathrm{Li}, \mathrm{Na}$, methane, ethane, and propane of any site, and it resembles the Torishima sites in $\mathrm{Br}$.

\section{EVIDENCE FOR UPWELLING OF PORE WATERS THROUGH CONICAL SEAMOUNT}

In 1987, divers in the submersible Alvin discovered chimneys at the summit of Conical Seamount, up to $3.5 \mathrm{~m}$ tall, composed either of aragonite, calcite, and minor amounts of amorphous Mg-silicate, or of amorphous Mg-silicate with trace amounts of carbonate (Fryer et al., 1987; Haggerty, 1987a; Fryer et al., 1990). On sampling, one of the latter type began to emit a slow flow of cold water high in $\mathrm{pH}(9.3)$, bicarbonate, methane, sulfate, and $\mathrm{H}_{2} \mathrm{~S}$ relative to seawater. Relative to carbonates of seawater origin that form in fracture zone serpentinites, the chimney carbonates were found to be depleted in $\mathrm{Sr}$ and $13_{\mathrm{C}}$ and enriched in $\mathrm{Mg}$ and $18_{\mathrm{O}}$ (Haggerty, 1987b). These isotopic data indicate that the carbonate originated from oxidation of methane

Table 1. Comparison of pore water in serpentine silts from two forearc seamounts.

\begin{tabular}{|c|c|c|c|c|c|}
\hline & \multicolumn{2}{|c|}{$\begin{array}{l}\text { Conical Seamount } \\
\text { Site } 780\end{array}$} & \multicolumn{3}{|c|}{$\begin{array}{c}\text { Torishima Forearc Seamount } \\
\text { Sites } 783,784\end{array}$} \\
\hline \multicolumn{6}{|c|}{ Relative to seawater: } \\
\hline & Enriched & Depleted & Enriched & Depleted & Unchanged \\
\hline $\mathrm{Cl}$ & & $\mathrm{x}$ & & & $\mathrm{x}$ \\
\hline $\mathrm{Br}$ & & $\mathrm{x}$ & & & $\mathrm{X}$ \\
\hline $\mathrm{pH}$ & 12.6 & & 10 & & \\
\hline Alkal'y & $x 26$ & & & $\mathrm{X}$ & \\
\hline $\mathrm{NH}_{3}$ & $\mathrm{X}$ & & $\mathrm{X}$ & & \\
\hline $\mathrm{CH}_{4}^{3}$ & $\mathrm{X}$ & & & low & \\
\hline Ethane & $\mathrm{X}$ & & & none & \\
\hline Propane & $\mathrm{x}$ & & & none & \\
\hline $\mathrm{H}_{2} \mathrm{~S}$ & $\mathrm{x}$ & & & none & \\
\hline & $x 1.7$ & & & $\mathrm{X}$ & \\
\hline${ }^{34} \mathrm{~S}{ }^{332} \mathrm{~S}$ & & $\mathrm{X}$ & $x$ & & \\
\hline $\mathrm{Si}$ & & $\mathrm{X}$ & & $\mathrm{x}$ & \\
\hline B & $x 10$ & & & $x$ & \\
\hline $\mathrm{Li}$ & & $\mathrm{X}$ & & $\mathrm{X}$ & \\
\hline $\mathrm{Na}$ & & $\mathrm{x}$ & & & $x$ \\
\hline $\mathrm{Na} / \mathrm{Cl}$ & x2 & & & & $\mathrm{X}$ \\
\hline $\mathrm{K}$ & $\mathrm{x} 1.5$ & & & $\mathrm{X}$ & \\
\hline $\mathrm{Rb}$ & $\times 5.6$ & & & $\mathrm{X}$ & \\
\hline $\mathrm{Mg}$ & & $\mathrm{X}$ & & $\mathrm{X}$ & \\
\hline $\mathrm{Ca}$ & & $\mathrm{x}$ & $\times 5.7$ & & \\
\hline $\mathrm{Sr}$ & & $\mathrm{x}$ & $\times 20$ & & \\
\hline $\mathrm{Ba}$ & & $x$ & $x$ & & \\
\hline Mn & & low & & low & \\
\hline
\end{tabular}




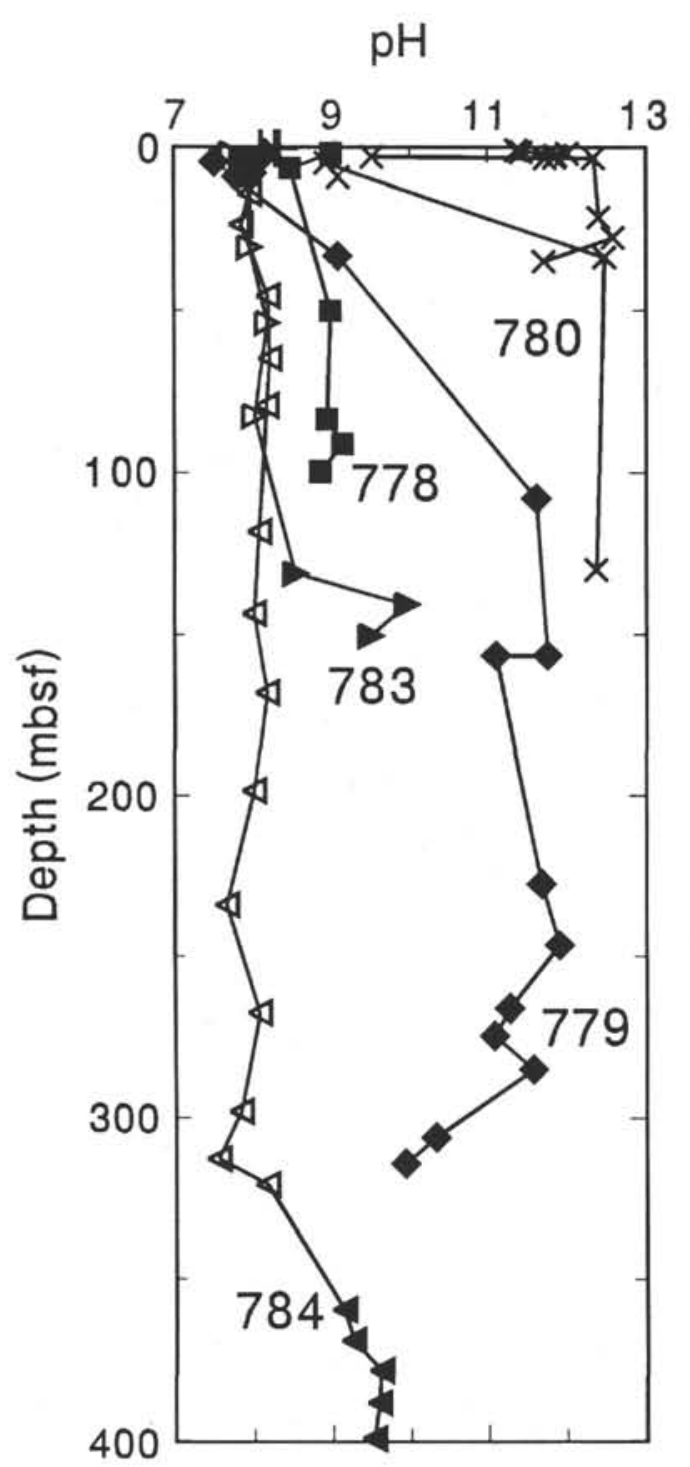

Alkalinity $(\mathrm{meq} / \mathrm{kg})$

$\mathrm{NH}_{3}(\mu \mathrm{mol} / \mathrm{kg})$
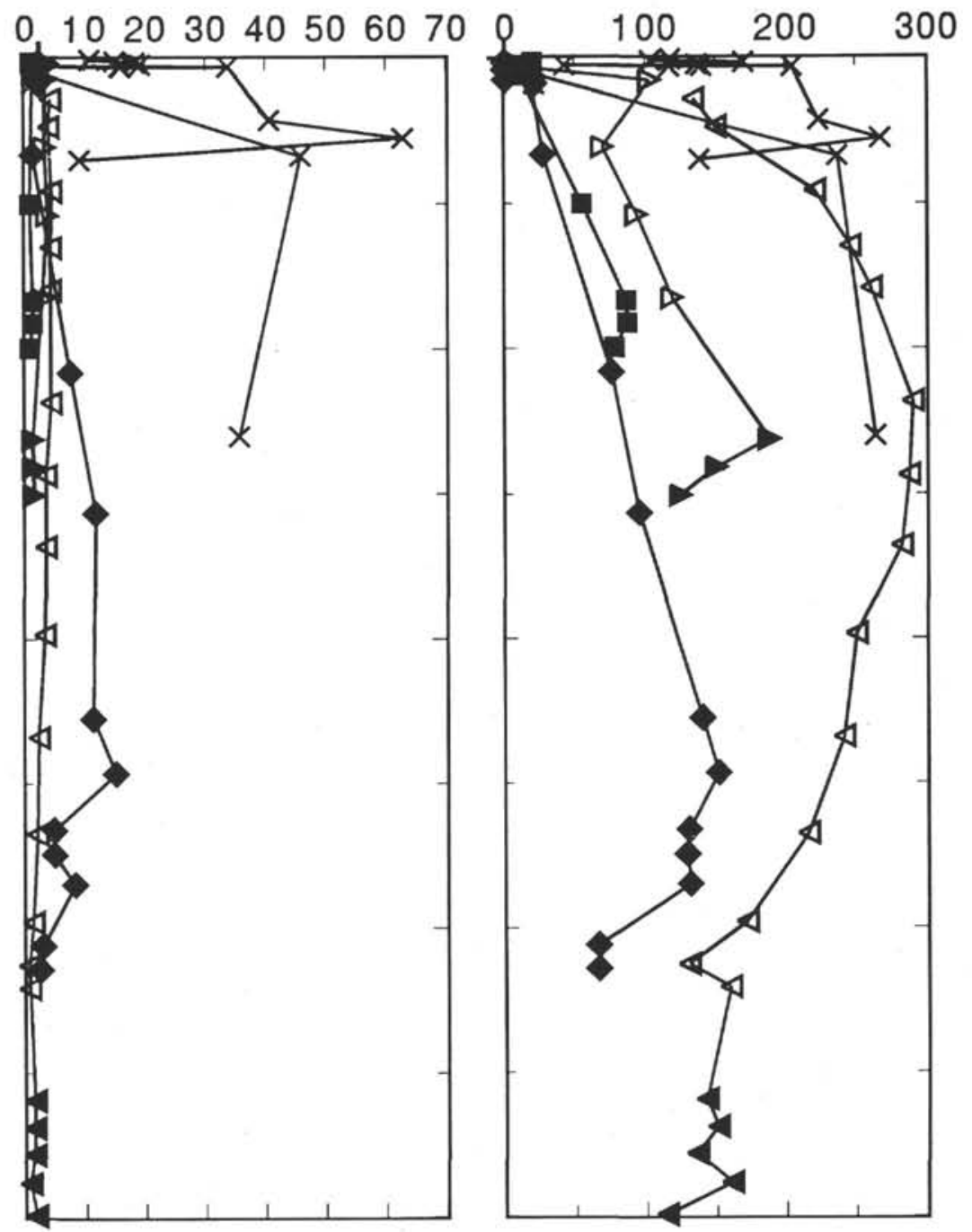

Figure 4. Composition of pore waters from cores at Sites 778 (squares), 779 (diamonds), 780 (x's), 783 (right-pointing triangles), and 784 (left-pointing triangles), compared with the composition of surface seawater (+'s on x-axis). For Sites 783 and 784, samples from claystone are shown by open triangles and samples from serpentine by solid triangles.

as well as from seawater, and methane was found in fluid inclusions along with aromatic compounds, long-chain paraffins, naphthenes, and acetate ions (Haggerty, 1989). The presence of aromatic compounds in the chimneys and of ethane and propane along with methane in the pore waters indicates a thermogenic origin for the organic compounds. The presence of acetate ions limits the temperature range in the source region of the organics to less than $150^{\circ} \mathrm{C}$. Similar methane-derived carbonate chimneys have been described from the Oregon subduction zone (Kulm et al., 1986; Ritger et al., 1987; Kulm and Suess, 1990). The summit of Conical Seamount is well below the aragonite compensation depth (Berger, 1970), and the bottom waters there are certainly undersaturated with aragonite ( $\mathrm{Li} \mathrm{et}$ al., 1969; Berner and Honjo, 1981).

Video photography taken during drilling of the A hole at summit Site 780 revealed no chimneys. The large gradients in pore-water composition in the surficial sediments, however, are almost certainly maintained by upflow of the freshened water through the central serpentine conduit of the seamount. These gradients cannot originate by reaction in the surficial sediments because the gradients are too steep and they exist for nearly every species measured and because the chemistry and mineralogy of the serpentine sediments are too simple. In the absence of upflow, the gradients would be quickly erased by diffusion to and from the overlying seawater. The steepness of the gradients suggests upflow velocities of a few millimeters per year (Fig. 10), much slower than the focused flow through the chimneys. The large variation in composition at a given depth among the four holes drilled within $150 \mathrm{~m}$ of each other indicates a patchy distribution of flow. Temperature logging yielded a value of $13.5^{\circ} \mathrm{C}$ at $58 \mathrm{mbsf}$ in Hole $780 \mathrm{C}$, vs. only $3.7^{\circ} \mathrm{C}$ extrapolated for the same depth from discrete measurements in Hole $780 \mathrm{D}$, and $1.52^{\circ} \mathrm{C}$ for bottom seawater. This suggests that warmer water from the bottom of the deepest Hole $780 \mathrm{C}$ at 164 mbsf flowed upward in the hole after it was drilled (Shipboard Scientific Party, 1990a-f).

In addition to the chimneys, upflow is almost certainly also responsible for extensive precipitation of aragonite needles in the serpentine silt at and near the seafloor, leading to carbonate enrichment in these zones at both the summit and flank sites (Fig. 11). Precipitation presumably occurs where the carbonate-rich, but $\mathrm{Ca}$ - 

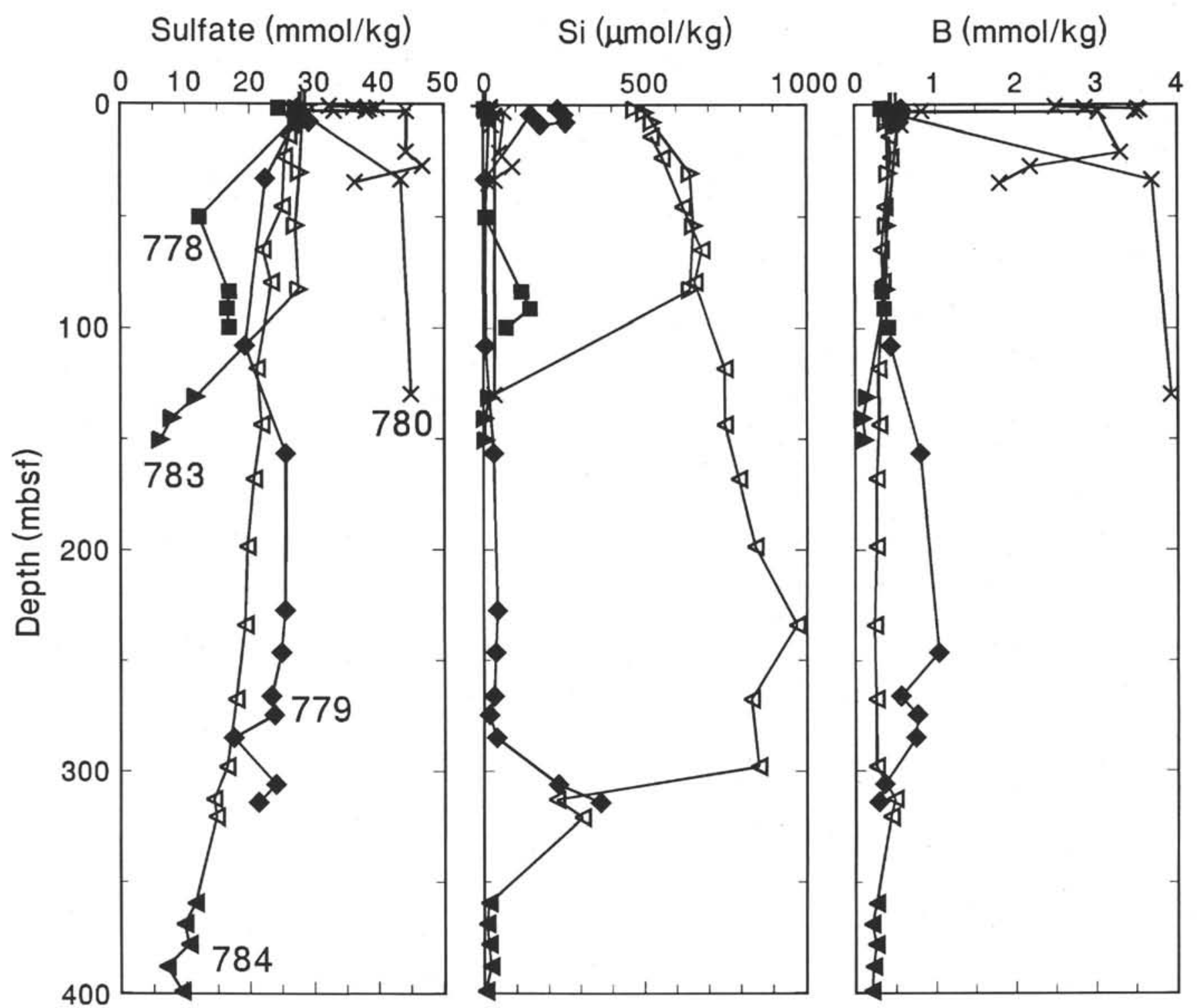

Figure 5. Composition of pore waters from cores at Sites 778, 779, 780, 783, and 784. Symbols are the same as in Figure 1.

poor, upwelling solutions mix with Ca-rich seawater. Site 784 on the Torishima Seamount flank shows a similar zone of carbonate enrichment near the top of the serpentine section in the form of dispersed calcite, rather than as discrete needles of aragonite. This enrichment suggests that Torishima Seamount may also have once vented solutions rich in carbonate ion and that the original aragonite has recrystallized.

\section{ORIGIN OF PORE WATERS AT CONICAL SEAMOUNT}

Two end-member hypotheses for the origin of the low-chlorinity pore waters at Conical Seamount must be considered: (1) the fluids originate mainly as seawater, and chloride is taken up into solid phases during alteration in greater proportion than is $\mathrm{H}_{2} \mathrm{O}$ and (2) the fluids do not originate mainly as seawater but contain a large component of freshwater that originates by some other process. Whatever the process that causes the chlorinity decrease at Site 780 , it must be occurring at a greater depth than was penetrated by drilling. The steep gradients in chlorinity and other dissolved species in the surficial sediments require upflow of pore water, as noted earlier. The persistence of these surficial changes in pore-water composition to the maximum depth drilled indicates that the upwelling fluid originates at a greater depth and that the upwelling rate overwhelms the reaction rate within the drilled interval.

\section{Seawater-Rock Interaction and Chloride Uptake}

Chloride uptake into solid phases during serpentinization has been reported, although the conditions under which this phenomenon can occur and the nature of the chlorine-rich phases are unclear. Janecky and Seyfried (1986) performed experiments reacting seawater and $\mathrm{Mg}$-free and $\mathrm{Mg}$ - and sulfate-free seawater with peridotites at $200^{\circ} \mathrm{C}$ and $300^{\circ} \mathrm{C}$ and a pressure of 500 bars. They found that dissolved chloride behaved conservatively when seawater was the reactant solution but that significant chloride was taken up into partially serpentinized harzburgite when the starting solution lacked $\mathrm{Mg}$. The distinctive feature of the $\mathrm{Mg}$-free-seawater experiments was the high $\mathrm{pH}$ in the solutions, which reached 11.5 in the longest experiment. This experiment was performed at $300^{\circ} \mathrm{C}, 500$ bars, and with a water/rock mass ratio of 10 , and ran for 714 days. The loss of chloride 


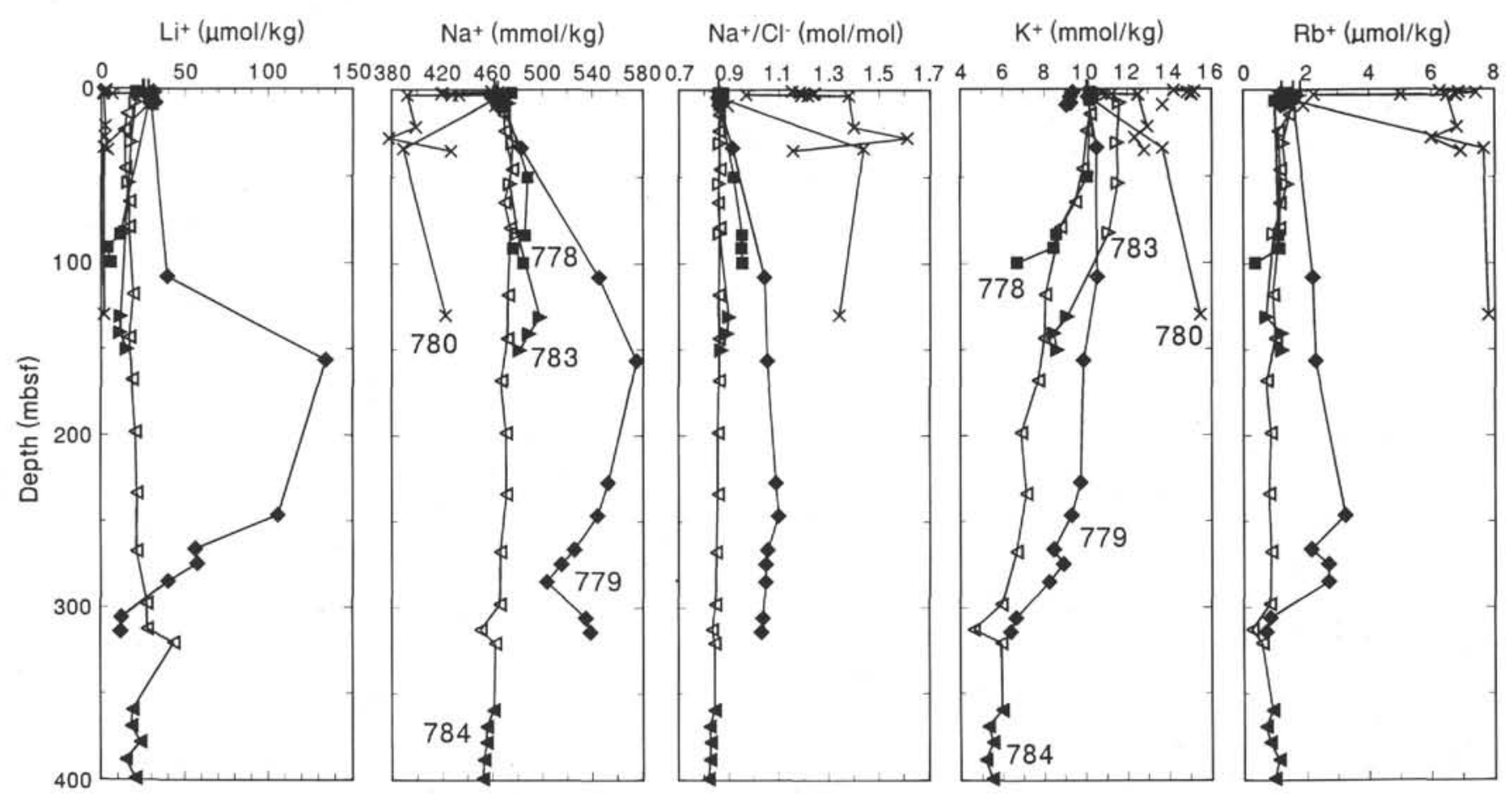

Figure 6. Composition of pore waters from cores at Sites 778, 779, 780, 783, and 784. Symbols are the same as in Figure 1.

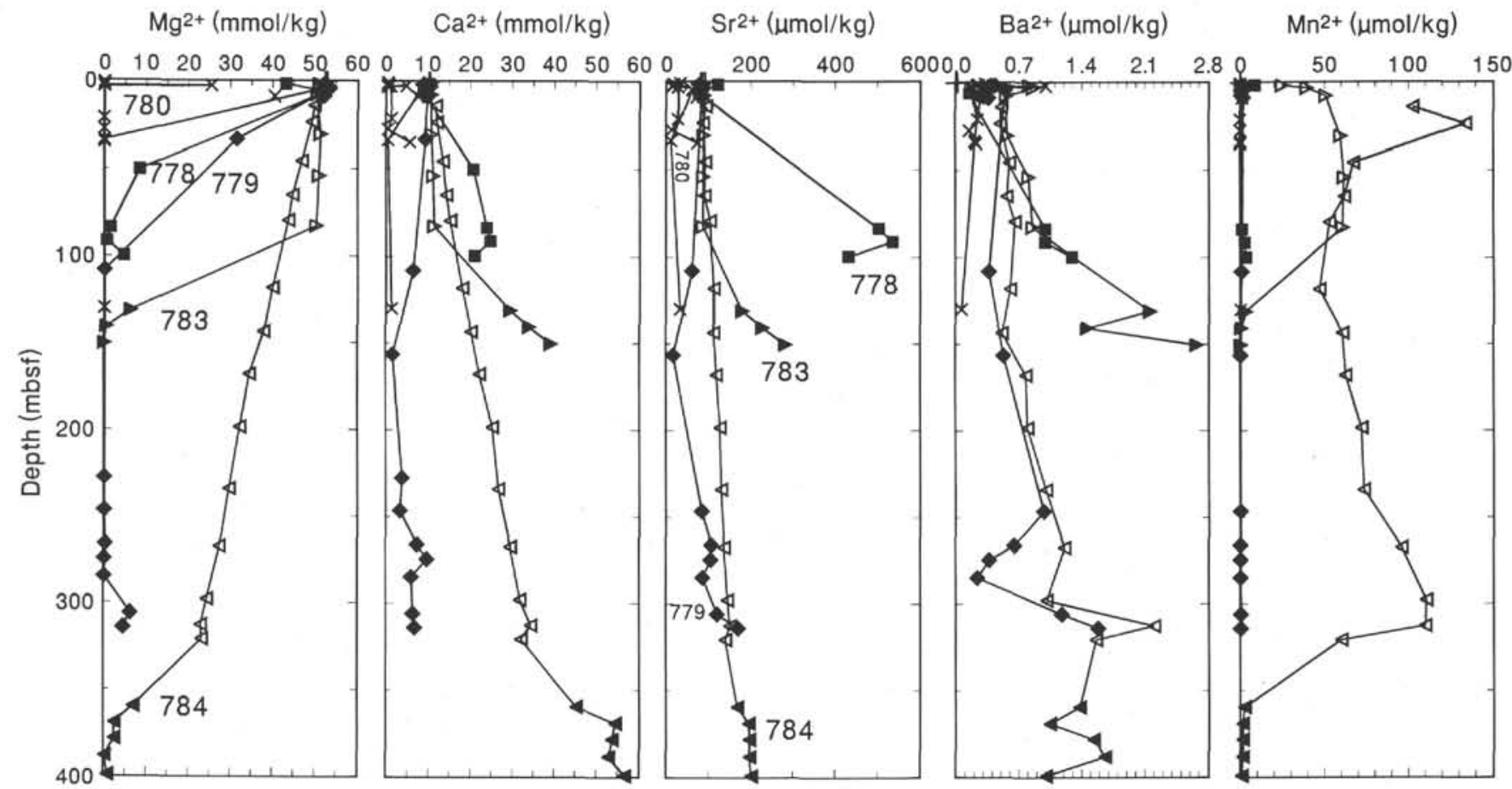

Figure 7. Composition of pore waters from cores at Sites 778, 779, 780, 783, and 784. Symbols are the same as in Figure 1.

from solution was $27 \mathrm{mmol} / \mathrm{kg}$, indicating that the altered harzburgite must have contained about $10,000 \mathrm{ppm}$, or $1 \mathrm{wt} \%$, chloride that it had picked up from solution during the experiment. Janecky and Seyfried (1986) were unable to determine in what solid phase or phases this chloride resided. They considered several possibilities: (1) a $\mathrm{Mg}-\mathrm{Fe}-$ chloride mineral like iowaite, which has been reported from serpen- tinites (Kohls and Rodda, 1967) and which occurs in minor amounts in some samples from the Conical Seamount sites (Fryer and Mottl, this volume; Heling and Schwarz, this volume); (2) an Fe-hydroxidechloride phase, such as was suggested to occur in serpentinites by Rucklidge (1972) and Rucklidge and Patterson (1977); (3) a Mghydroxide-chloride phase, $\mathrm{Mg}_{2}(\mathrm{OH})_{3} \mathrm{Cl}$, produced during experimen- 
Chlorinity $(\mathrm{mmol} / \mathrm{kg})$

$\mathrm{Br}^{-}(\mu \mathrm{mol} / \mathrm{kg})$

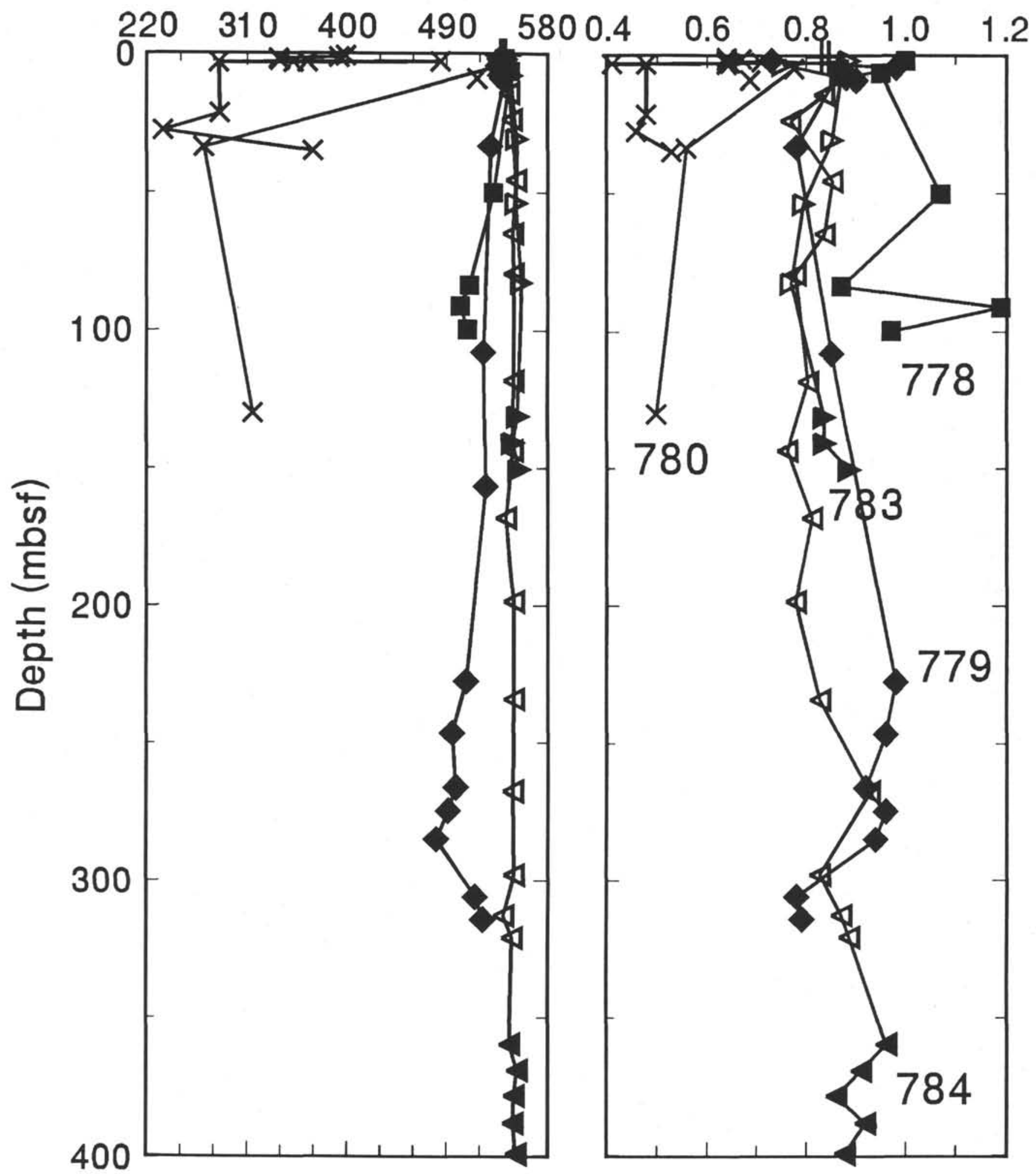

Figure 8. Composition of pore waters from cores at Sites 778, 779, 780, 783, and 784. Symbols are the same as in Figure 1. 


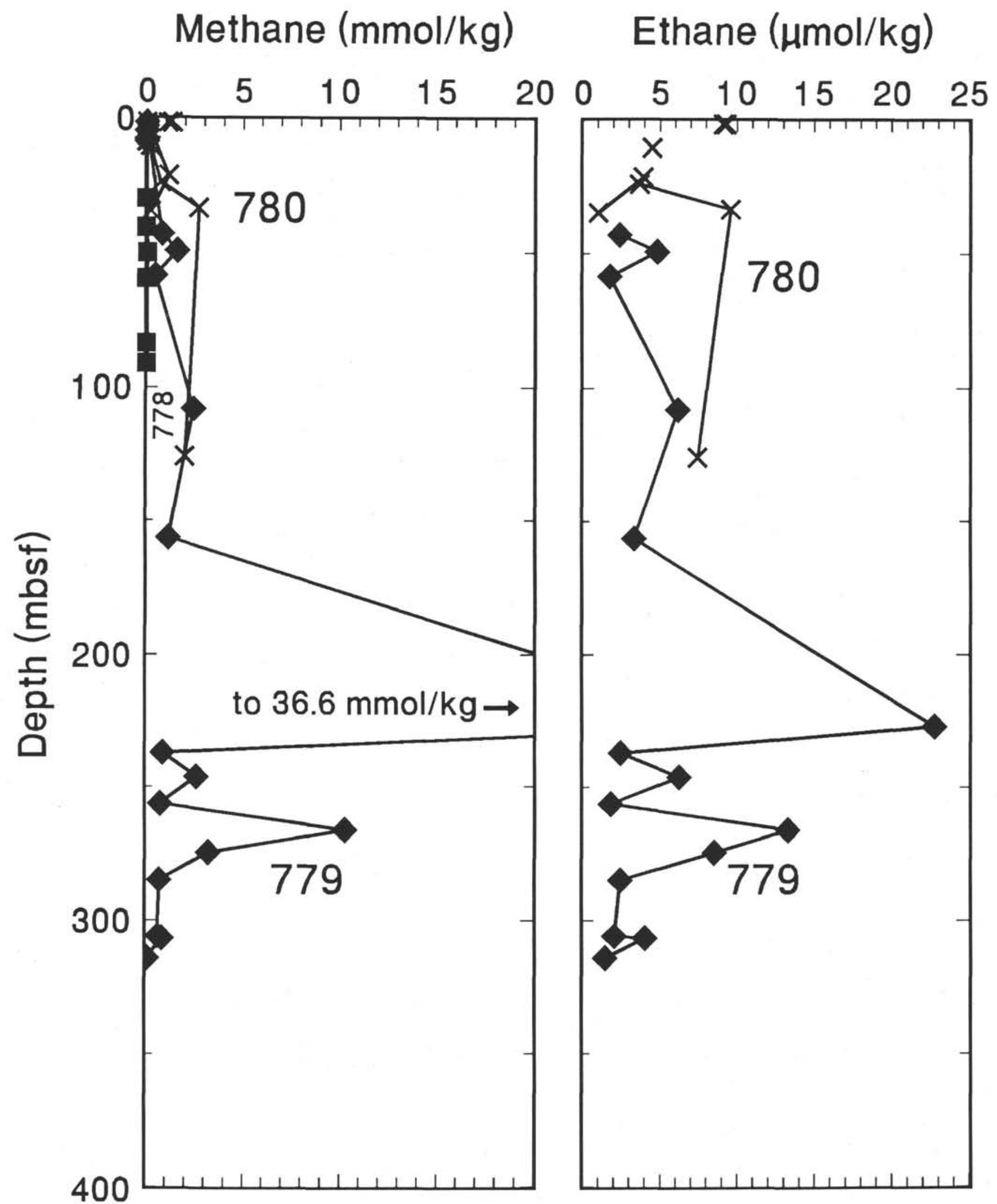

Figure 9. Composition of pore waters from cores at Sites 778, 779, and 780, in mmol/kg of pore water. Symbols are the same as in Figure 1. Methane concentrations at Sites 783 and 784 are even lower than those at Site 778 , and ethane is absent at these three sites. 


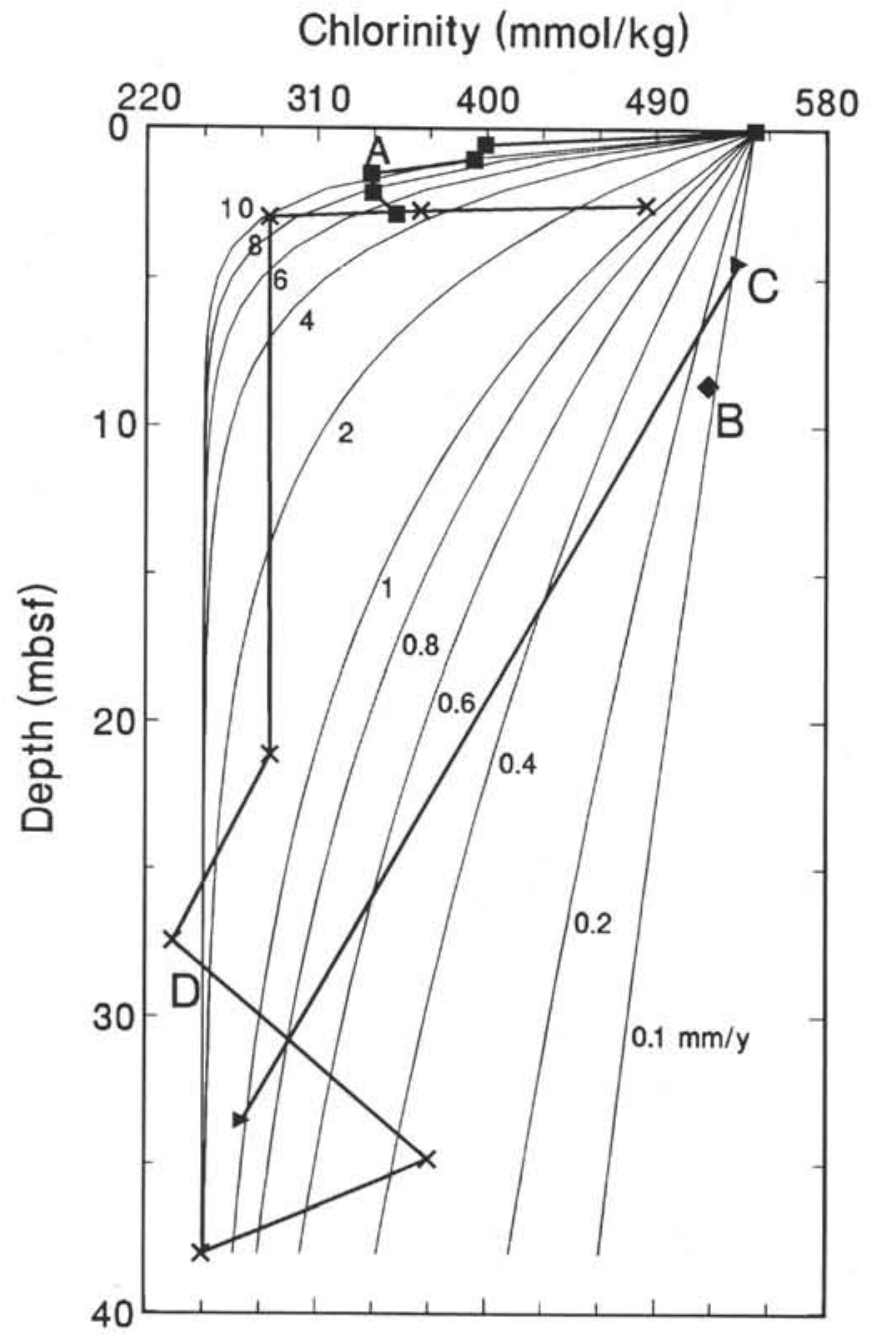

Figure 10. Chlorinity of pore waters from Holes A through D at Site 780 on the summit of Conical Seamount, compared with profiles calculated from a one-dimensional advection-diffusion model (Bredehoeft and Papadopulos, 1965) for upwelling at Darcy velocities of 0.1 to $10 \mathrm{~mm} / \mathrm{yr}$, assuming a sediment diffusion coefficient that is constant with depth at a value of $0.0132 \mathrm{~m}^{2} / \mathrm{yr}(4.18$ $\left.\times 10^{-6} \mathrm{~cm}^{2} / \mathrm{s}\right)$. The sediment diffusion coefficient $\left(D_{\mathrm{s}}\right)$ was calculated from $\mathrm{Li}$ and Gregory's (1974) diffusion coefficient for chloride in water $\left(D_{w}\right)$ of 0.0363 $\mathrm{m} 2 / \mathrm{yr}$ at $5^{\circ} \mathrm{C}$, the measured porosity of about 0.55 , and the measured formation factor of about 5 (Shipboard Scientific Party, 1990), using the relation $D_{\mathrm{s}}=$

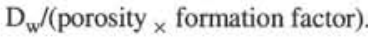

tal serpentinization at $500^{\circ} \mathrm{C}$ and 1000 bars by Poty et al. (1972); (4) newly formed, poorly crystallized serpentines that might retain chloride in their structure, as was suggested by Miura et al. (1981); and (5) poorly crystallized brucite. Given that the chloride decrease in the longest experiment was balanced nearly mole for mole by $\mathrm{Na}$, the latter two possibilities may be most likely. The $<2.98-\mathrm{g} / \mathrm{cm}^{3}$ fraction separated from the altered solids from this experiment contained $1.59 \mathrm{wt} \% \mathrm{Na}_{2} \mathrm{O}$, although for some reason this $\mathrm{Na}$ did not appear in the bulk analysis of the altered rock, which yielded only $0.07 \mathrm{wt} \%$.

The large decreases in chlorinity of the pore waters at Site 780, relative to seawater, are balanced only one-quarter to one-third by decreased $\mathrm{Na}$. When the nearly complete removal of $\mathrm{Mg}$ and $\mathrm{Ca}$ from solution is included as well, only three-quarters of the negative charge loss can be accounted for. The other one-quarter is balanced about equally by the large gains in sulfate and alkalinity. Relative to sea- water, the increase in sulfate is proportionally about equal to that in $\mathrm{K}$. If the gains in sulfate and $\mathrm{K}$ are caused mainly by loss of $\mathrm{H}_{2} \mathrm{O}$ from seawater to the serpentinized rocks, and the rocks gain on average about $12 \mathrm{wt} \% \mathrm{H}_{2} \mathrm{O}$, then each gram of seawater would have reacted with and hydrated 2 to $3 \mathrm{~g}$ of fresh rock. If the rock also took up chloride under these conditions, it would have to gain about 4300 ppm, or $0.43 \mathrm{wt} \%$ chloride, to account for the chloride decrease observed in the interstitial waters at Site 780. This is well within the range of uptake that apparently occurred in the experiments of Janecky and Seyfried (1986), indicating that chloride uptake below the drilled interval could account for the freshening observed in the pore waters at Site 780. The high concentrations of alkalinity, methane, and ammonia could also be explained by this model, as there are adequate concentrations of carbonate and organic carbon and nitrogen in the solids, as measured within the drilled interval (Shipboard Scientific Party, 1990a-f), to account for the concentrations in the pore waters.

However, the very different manner in which charge is balanced at Site 780 vs. in the experiments, noted above, strongly suggests that some other process has dominated at Conical Seamount summit. In addition, the assumption in the above model that sulfate is conservative is highly unlikely in view of the large decrease in $\delta^{34} \mathrm{SO}_{4}$ at Site 780 (Mottl and Alt, this volume). The chloride-uptake model by itself cannot explain many of the other chemical changes in the Conical summit pore waters relative to seawater, including the large decreases in $\mathrm{Br}, \mathrm{Li}, \mathrm{Na}, \mathrm{Ca}, \mathrm{Sr}$, and $\mathrm{Ba}$, which would have to be taken up into the rock along with chloride during alteration, and the large increases in $\mathrm{B}$ and $\mathrm{Rb}$, which would have to be leached from the rock. These directions of net transport between solids and solution are very different from what was observed at Torishima Seamount, where there is no evidence of any fluid other than reacted seawater. Neither chlorinity nor $\mathrm{Br}$ decreases in pore waters from the serpentine section at Torishima; in fact, they increase slightly with depth. Methane is present only in very low concentrations, and ethane and propane are absent. Values of $\delta^{34} \mathrm{SO}_{4}$ increase due to sulfate reduction, probably by bacteria (Mottl and Alt, this volume). $\mathrm{Li}, \mathrm{Na}$, and $\mathrm{Rb}$ change little, whereas $\mathrm{Ca}, \mathrm{Sr}, \mathrm{Ba}, \mathrm{K}, \mathrm{B}$, alkalinity, and sulfate change in the opposite direction to what was found at the Conical Seamount summit. The pore waters at Torishima can be taken as end-member examples of harzburgite-seawater interaction at relatively low temperatures and are very different from the pore waters that are flowing upward through the Conical Seamount summit (Table 1).

\section{Evidence from Drilling in Other Subduction Zones}

Low-chlorinity interstitial waters have been sampled from drill holes in other subduction zones, including the Japan Trench, the Middle America Trench off Guatemala and Mexico, the Barbados accretionary prism, and the Peru continental margin. In the Japan Trench, at Sites 438 and 439 drilled during DSDP Leg 57, the chlorinity of the pore waters decreases with depth to half the value in seawater at 900 to 1000 mbsf. Moore and Gieskes (1980) suggested that this low-chlorinity water originated from a fossil aquifer.

In the Middle America Trench off Guatemala, the chlorinity of the pore waters is lower than that of seawater by up to $54 \%$ at $337 \mathrm{mbsf}$ at Site 570 and at 395 mbsf at Site 497 . Chlorinity also is lower by $6 \%$ to $41 \%$ at Sites 490,491 , and 492 , drilled during DSDP Leg 66 off Mexico (Gieskes et al., 1985); Site 496, drilled during DSDP Leg 67 off Guatemala (Hesse and Harrison, 1981; Harrison et al., 1982); and Sites 565 and 568, drilled during DSDP Leg 84 off Guatemala (Hesse et al., 1985). The decrease in chlorinity at all these sites in the Middle America Trench has been attributed to the presence of hydrocarbon gas hydrates in the sediments. These hydrates decompose to methane and water during core recovery as a result of decompression and warming. In addition, Aubouin and von Huene (1985) suggested that the hydrocarbon gas hydrates at Site 570, which were present in serpentinite basement at the bottom of the hole as well 
$\mathrm{CaCO}_{3}(\mathrm{wt} \%)$

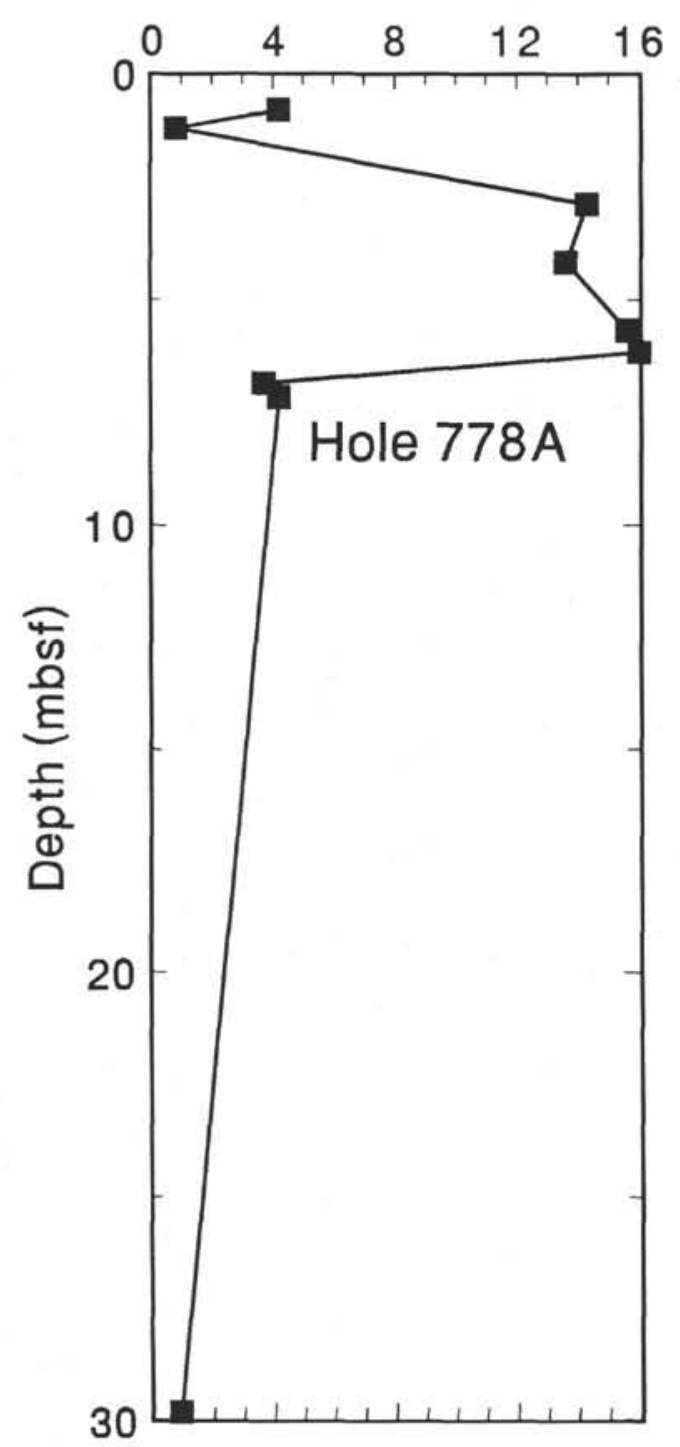

$\mathrm{CaCO}_{3}(\mathrm{wt} \%)$

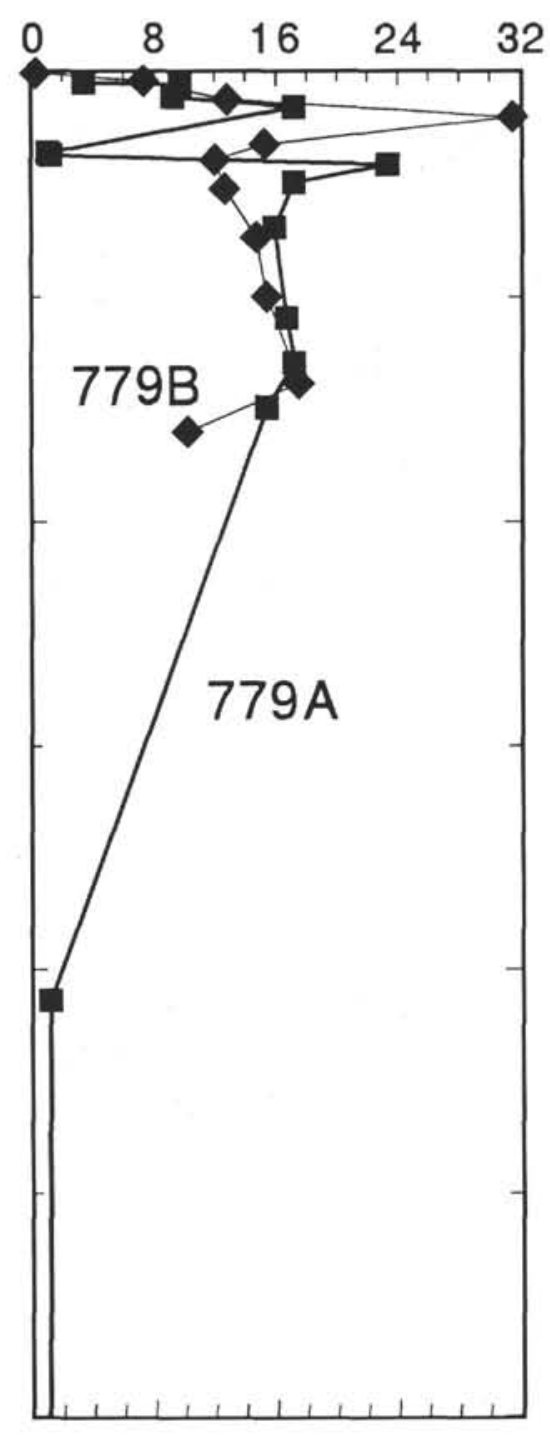

$\mathrm{CaCO}_{3}(\mathrm{wt} \%)$

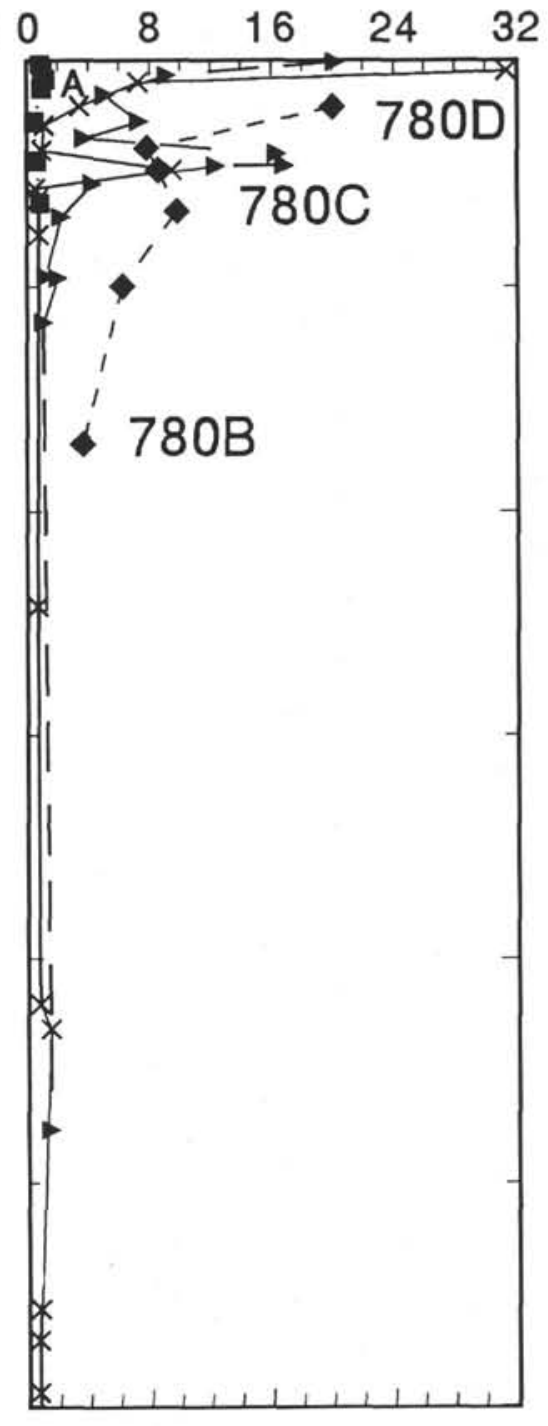

Figure 11. Concentration of calcium carbonate in the upper $30 \mathrm{~m}$ of serpentine silt at Sites 778,779 , and 780 . The low concentrations typical of the interval between 20 to 30 mbsf persist to the maximum depths drilled.

as in the overlying sediments, originated by upward migration of gas and fresh water (von Huene and Lee, 1983) from subducted sediment.

On the Northern Barbados Ridge, drilled during Leg 110, chlorinity is lower than that in seawater by up to $28 \%$ at Site 674 , but by less than $12 \%$ at all other sites drilled there. This decrease was tentatively attributed by the Shipboard Scientific Party (1988a) to an ultrafiltration process, in which clay minerals act as semipermeable membranes, selectively passing $\mathrm{H}_{2} \mathrm{O}$ but restricting the transport of ionic species. On the basis of additional data, Gieskes et al. (1990) attributed the decrease to dehydration of clays and to deeper prograde diagenetic and metamorphic dehydration reactions. All of these processes were postulated to occur deeper than the maximum depth drilled; the freshwater produced is thought to move upward along faults and other permeable pathways, and especially along the shallowly inclined décollement surface.

On the Peru continental margin, chlorinity increases greatly with depth at five sites drilled during ODP Leg 112 and decreases at the other five. At Site 679, these decreases are up to $38 \%$ relative to seawater, but they are less than $18 \%$ at the other four sites. Several processes may have contributed to these decreases in chlorinity, including decomposition of hydrocarbon gas hydrates, membrane filtration, dewatering of clays and opal, and the possible presence of fossil freshwater (Suess et al., 1988; Elderfield et al., 1990; Kastner et al., 1990). Several chlorinity maxima and minima at Sites 682, 683, 685 , and 688 clearly result from formation and decomposition, respectively, of gas hydrates at corresponding depths in the drill holes. As in the case of the Barbados accretionary prism, however, the larger-scale decrease with depth indicates that the major source of freshwater lies below the maximum depth drilled. This freshwater is thought to have risen upward along permeable channels consisting of unconformities, coarse-grained sedimentary units, and conjugate and intersecting fracture zones (Shipboard Scientific Party, 1988b).

\section{Possible Sources of Low-Chlorinity Water at Conical Seamount}

The $57 \%$ decrease in chlorinity at $27 \mathrm{mbsf}$ in Hole $780 \mathrm{D}$ is larger than any observed in sediment pore waters above subduction zones elsewhere. 


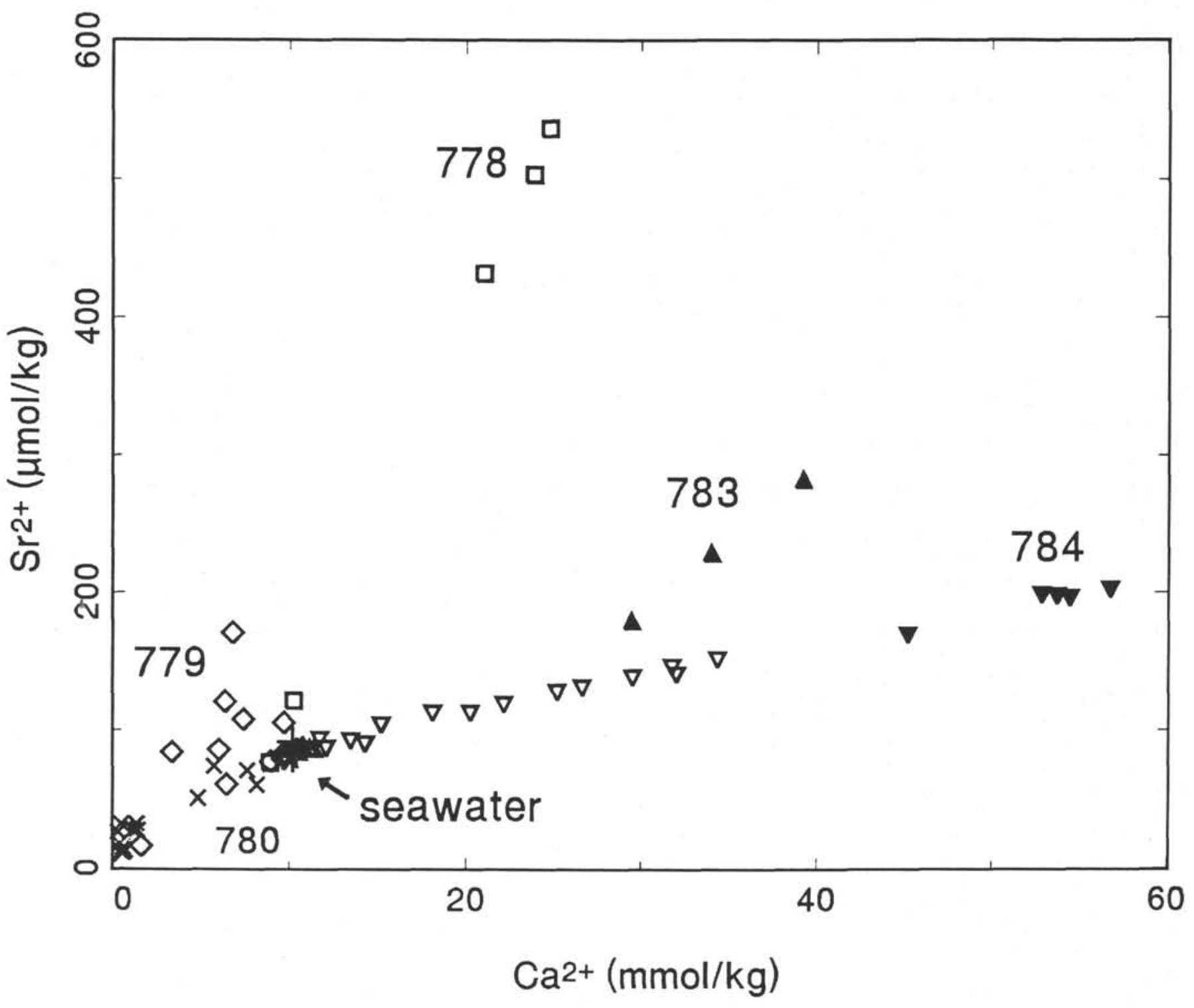

Figure 12. Concentration of Ca vs. Sr in pore waters from Sites 778, 779, 780, 783, and 784, compared with seawater ( $\times$ 's). Other symbols are the same as in Figure 1.

It has also been sampled at much shallower depths below the seafloor, as a result of upflow of pore waters through the summit of Conical Seamount. The explanations suggested for freshening of pore waters in other subduction zones must be considered for Conical Seamount.

No direct evidence of hydrocarbon gas hydrates was found in any of the cores during Leg 125, nor is there convincing seismic evidence of a bottom-simulating reflector that might indicate their presence. Given the temperature gradient of about $0.038^{\circ} \mathrm{C}$ measured in Hole $780 \mathrm{D}$, however, the phase diagram for methane hydrate (Kvenvolden and McMenamin, 1980) suggests that this phase should be stable from the seafloor to a depth of about $600 \mathrm{mbsf}$ beneath the summit Site 780 , below which temperatures exceeding about $24^{\circ} \mathrm{C}$ would cause any gas hydrate present to melt. Gas hydrate will form, of course, only if methane concentrations are sufficiently high, in excess of about 58 $\mathrm{mmol} / \mathrm{kg}$, according to Claypool and Kaplan (1974). The highest concentration measured at Site 780 was only $2.7 \mathrm{mmol} / \mathrm{kg}$, and at flank Site $779,36.6 \mathrm{mmol} / \mathrm{kg}$. These concentrations are minima, however, because of probable degassing during core recovery, which can be avoided only by use of a core barrel capable of maintaining in situ pressure. The large maximum in light hydrocarbons measured in Hole 779A at $227 \mathrm{mbsf}$, and other maxima deeper in the same hole, may result from melting of gas hydrate during core recovery, but there is no correlation between the hydrocarbon maxima and chlorinity decreases. Thus, the evidence is inconclusive. Gas hydrates could be present in a zone between the maximum depth drilled and about 600 mbsf, at which depth they might continuously melt, supplying freshwater and dissolved hydrocarbon gases that may upwell to the summit if diluted somewhat by seawater during the ascent to prevent refreezing. Note, however, that methane concentrations are up to 12 times higher at flank Site 779 than at summit Site 780, yet the decrease in chlorinity is much smaller at Site 779: only $9 \%$ lower than seawater, compared with $57 \%$ lower at Site 780 . Unless methane and water derived from melting of gas hydrates are somehow separated from each other during ascent through the upper few hundred meters of 
Conical Seamount, this discrepancy suggests that decomposition of gas hydrates is probably not the dominant source of freshwater on Conical Seamount.

The low abundance of clay minerals in the rocks and sediments recovered from Conical Seamount, along with the absence of a large volume of sedimentary substrate in the Mariana forearc in general, makes membrane filtration through clay minerals an unlikely mechanism for generating freshwater there. Conical Seamount is too far from land for any fossil freshwater aquifers to be present.

Dehydration of hydrous minerals at depth beneath Conical Seamount is therefore the most likely mechanism for generating freshwater. The chemistry of the pore waters sampled at Sites 778, 779, and 780 , especially the high $\mathrm{pH}$, indicates that the drilled interval is undergoing serpentinization at the present time. Thus, any dehydration of previously formed hydrous minerals would have to be taking place well below the maximum depth drilled during Leg 125 and would have to supply enough $\mathrm{H}_{2} \mathrm{O}$ both for serpentinization at shallower depths and to feed the freshened pore waters upwelling through Conical Seamount.

Possible dehydration reactions that could supply fluids in a subduction zone, discussed by Peacock (1990, and references therein), include (1) diagenetic transformation of opal- $\mathrm{A}$, including expulsion of interlayer water at about $30^{\circ}$ to $80^{\circ} \mathrm{C}$; (2) expulsion of interlayer water from smectite and its transformation to illite at about $50^{\circ}$ to $150^{\circ} \mathrm{C}$; (3) metamorphic dehydration of sedimentary minerals, mainly clays, beginning at about $250^{\circ}$ to $300^{\circ} \mathrm{C}$; and (4) metamorphic dehydration of chlorite, amphibole, and other hydrous phases in the basaltic oceanic crust, beginning at about $450^{\circ}$ to $500^{\circ} \mathrm{C}$. These dehydration reactions would be accompanied by breakdown of hydrocarbons to methane in sediments at about $60^{\circ}$ to $150^{\circ} \mathrm{C}$ and by decarbonation of sedimentary carbonates. As noted earlier, the organic compounds in the pore waters of Conical Seamount are thermogenic, and the presence of acetate ions in fluid inclusions in the carbonate chimneys there limits the temperature range in the source region to less than $150^{\circ} \mathrm{C}$ for at least some of the organic molecules (Haggerty, 1989). As there is little pelagic sediment in the Mariana forearc crust, the most likely source of sedimentary material is that at the top of the subducting slab $30 \mathrm{~km}$ below Conical Seamount, where subducted basaltic crust also is available. The thermal models of Peacock (1990) for a subducting slab suggest temperatures in the range of $150^{\circ}$ to $600^{\circ} \mathrm{C}$ at the pressure at this depth of about $10 \mathrm{kbar}$. Water driven from these subducted oceanic sediments and basement could serpentinize the overlying wedge of mantle, resulting in serpentine mud volcanoes such as Conical Seamount, as well as the unusual pore fluids upwelling through its summit.

\section{Evidence for Mixing of Fluids from Several Sources}

If the pore waters upwelling through Conical Seamount summit do in fact originate largely from dehydration of the subducting oceanic crust, then the relative simplicity of their serpentine host matrix, both chemically and mineralogically, should provide us with the clearest picture to date of what such a fluid component looks like. From the composition of the pore waters at Site 780 , we can infer that it is rich in $\mathrm{H}_{2} \mathrm{O}, \mathrm{C}$ both as dissolved carbonate species and as light hydrocarbons and other organic molecules, and $\mathrm{S}$ as both sulfate and $\mathrm{H}_{2} \mathrm{~S}$. It is depleted in ${ }^{34} \mathrm{~S}$ relative to seawater. By comparison with pore waters from Torishima Seamount that result from harzburgite-seawater interaction, we can also infer that it is rich in $\mathrm{B}, \mathrm{Na}, \mathrm{K}$, and $\mathrm{Rb}$.

For other species, the picture is less clear. The pore waters from the summit of Conical Seamount have low concentrations of $\mathrm{Mg}, \mathrm{Mn}$, and $\mathrm{Si}$, but so do those from serpentine at Torishima Seamount. They also have much lower $\mathrm{Li}, \mathrm{Ca}, \mathrm{Sr}$, and $\mathrm{Ba}$ than at Torishima, but this probably results from the much higher concentrations of carbonate alkalinity and sulfate associated with the deep-fluid component at Conical, and from the much higher $\mathrm{pH}$. Ammonia is somewhat higher at Conical than in the Torishima serpentines for reasons that are unclear. The organic carbon content of the serpentine sediments on both seamounts is generally in the range of 0.1 to $0.3 \mathrm{wt} \%$ (Shipboard Scientific Party, 1990a-f). Sulfate decreases greatly in the Torishima pore waters within the serpentine-rich section, whereas its ${ }^{34} S{ }^{32} S$ ratio increases, presumably as a result of bacterial sulfate reduction using this organic matter. Although the alkalinity increase expected from this reaction is prevented by a high concentration of $\mathrm{Ca}$ leached from the rock, ammonia increases as expected. The increase in ammonia at Conical Seamount summit may result from the same process of sulfate reduction; some $\mathrm{H}_{2} \mathrm{~S}$ is present there, but any decrease in sulfate is masked by the sulfate supplied with the deepfluid component.

In summary, the deep-fluid component, as typified by Conical Seamount summit Site 780 , is characterized by high carbonate alkalinity, methane, ethane, propane, sulfate, $\mathrm{H}_{2} \mathrm{~S}, \mathrm{~B}, \mathrm{Na}, \mathrm{K}$, and $\mathrm{Rb}$; and low chlorinity, $\mathrm{Br}, \mathrm{Li}, \mathrm{Ca}, \mathrm{Sr}, \mathrm{Ba}$, and ${ }^{34} \mathrm{~S} /{ }^{32} \mathrm{~S}$. The component derived by reaction of seawater with peridotite, as typified by the serpentine section at Torishima Seamount Sites 783 and 784 , is characterized by very low methane; absence of ethane and propane; low carbonate alkalinity, sulfate, $\mathrm{B}$, and $\mathrm{K}$; slightly lower Li and $\mathrm{Rb}$; little-changed chlorinity, $\mathrm{Br}, \mathrm{Na}$, and $\mathrm{Na} / \mathrm{Cl}$; and high $\mathrm{Ca}, \mathrm{Sr}, \mathrm{Ba}$, and ${ }^{34} \mathrm{~S} /{ }^{32} \mathrm{~S}$. Both components have high $\mathrm{pH}$ and ammonia and low $\mathrm{Mg}$, $\mathrm{Si}$, and $\mathrm{Mn}$ (Table 1). To a first approximation, Conical Seamount flank Sites 778 and 779 are mixtures of these two fluid components, Site 779 being richer in the deep-fluid component than Site 778 .

In addition to the general trends with depth, however, many of the dissolved species in pore waters at Conical Seamount show more complex profiles that include maxima and minima. This is especially true at flank Site 779, but it also occurs in the lowermost one or two samples in Holes 778A and 780D. Pore waters from closely spaced holes at Sites 779 and 780 also show large differences in composition at similar shallow depths beneath the sea floor. Both types of variation can be caused by mixing of fluids from different sources in a complex plumbing system within Conical Seamount. Besides the two endmember fluids described above, locally derived seawater may have reacted with mafic rocks in the vicinity of the seamount. Such reaction could explain the lower $\mathrm{pH}$ and higher $\mathrm{Si}$ at Site 778 , which has ubiquitous small mafic clasts suspended in the serpentine (Johnson, this volume) along with the ultramafic clasts that occur at all of the sites. Reaction with these mafic clasts could also explain the relatively high $\mathrm{Sr}$ concentrations and $\mathrm{Sr} / \mathrm{Ca}$ ratios in the pore waters from Site 778 (Fig. 12). Site 779 , with its complex profiles, may exhibit the effects of mixing of all three fluids at various depths. At least three separate fluids may be required for explaining the multiple maxima and minima of the various dissolved species, as they generally do not correlate with one another.

\section{ACKNOWLEDGMENTS}

This research was supported by the Ocean Drilling Program and by a grant from the Joint Oceanographic Institutions U.S. Science Support Program. This is School of Ocean and Earth Science and Technology contribution number 2618, University of Hawaii.

\section{REFERENCES}

Aubouin, J., and von Huene, R., 1985. Summary: Leg 84, Middle America Trench transect off Guatemala and Costa Rica. In von Huene, R., Aubuoin, J., et al., Init. Repts. DSDP, 84: Washington (U.S. Govt. Printing Office), 939-956.

Berger, W. H., 1970. Planktonic foraminifera: selective solution and the lysocline. Mar. Geol., 8:111-138.

Berner, R. A., and Honjo, S., 1981. Pelagic sedimentation of aragonite: its geochemical significance. Science, 211:940-942.

Bredehoeft, J. D., and Papadopulos, I. S., 1965. Rates of vertical groundwater movement estimated from the earth's thermal profile. Water Resourc. Res., $1: 325-328$. 
Claypool, G. E., and Kaplan, I. R., 1974. The origin and distribution of methane in marine sediments. In Kaplan, I. R. (Ed.), Natural Gases in Marine Sediments: New York (Plenum), 99-139.

Elderfield, H., Kastner, M., and Martin, J. B., 1990. Composition and sources of fluids in sediments of the Peru subduction zone. J. Geophys. Res., 95:8819-8827.

Fryer, P., Saboda, K. L., Johnson, L. E., Mackay, M. E., Moore, G. F., and Stoffers, P., 1990. Conical Seamount: SeaMARC II, Alvin submersible, and seismic reflection studies. In Fryer, P., Pearce, J. A., Stokking, L. B., et al., Proc. ODP, Init. Repts., 125: College Station, TX (Ocean Drilling Program), 69-80.

Gieskes, J. M., Johnston, K., and Boehm, M., 1985. Interstitial water studies, Leg 66. In von Huene, R., Aubouin, J., et al., Init. Repts. DSDP, 84: Washington (U.S. Govt. Printing Office), 961-967.

Gieskes, J. M., Vrolijk, P., and Blanc, G., 1990. Hydrogeochemistry of the northern Barbados accretionary complex transect: Ocean Drilling Program Leg 110. J. Geophys. Res., 95:8809-8818.

Haggerty, J., 1987a. Cold-water, deep-sea chimneys from the Mariana forearc serpentinite seamounts. Eos, 68:1534.

1987b. Geochemistry of carbonate and silicate chimney structures from Conical Seamount collected during Alvin dive studies. Eos, 68:1534 1989. Fluid inclusion studies of chimneys associated with serpentinite seamounts in the Mariana forearc. PACROFI II, 2:29.

Harrison, W. E., Hesse, R., and Gieskes, J. M., 1982. Relationship between sedimentary facies and interstitial water chemistry of slope, trench, and Cocos plate sites from the Middle America Trench transect, active margin of Guatemala, Deep Sea Drilling Project Leg 67. In Aubouin, J., von Huene, R., et al., Init. Repts. DSDP, 67: Washington (U.S. Govt. Printing Office), 603-613.

Hesse, R., and Harrison, W. E., 1981. Gas hydrates (clathrates) causing pore-water freshening and oxygen isotope fractionation in deep-water sedimentary sections of terrigenous continental margins. Earth Planet. Sci. Lett., 55:453-462.

Hesse, R., Lebel, J., and Gieskes, J. M., 1985. Interstitial water chemistry of gas-hydrate-bearing sections on the Middle America Trench slope, Deep Sea Drilling Project Leg 84. In von Huene, R., Aubouin, J., et al., Init. Repts. DSDP, 84: Washington (U.S. Govt. Printing Office), 727-737.

Janecky, D. R., and Seyfried, W. E., Jr., 1986. Hydrothermal serpentinization of peridotite within the oceanic crust: experimental investigations of mineralogy and major element chemistry. Geochim. Cosmochim. Acta, 50:1357-1378

Kastner, M., Elderfield, H., Martin, J. B., Suess, E., Kvenvolden, K. A., and Garrison, R. E., 1990. Diagenesis and interstitial-water chemistry at the Peruvian continental margin-major constituents and strontium isotopes. In Suess, E., von Huene, R., et al., Proc. ODP, Sci. Results, 112: College Station, TX (Ocean Drilling Program), 413-440.

Kohls, D. W., and Rodda, J. L., 1967. Iowaite, a new hydrous magnesium hydroxide-ferric oxychloride from the Precambrian of Iowa. Am. Mineral., 52:1261-1271.

Kulm, L. D., and Suess, E., 1990. Relationship between carbonate deposits and fluid venting: Oregon accretionary prism. J. Geophys. Res., 95:8899-8915.

Kulm, L. D., Suess, E., Moore, J. C., Carson, B., Lewis, B. T., Ritger, S. D., Kadko, D. C., Thornburg, T. M., Embley, R. W., Rugh, W. D., Massoth, G. J., Langseth, M. G., Cochrane, G. R., and Scamman, R. L., 1986. Oregon subduction zone: venting, fauna, and carbonates. Science, 231:561-566.

Kvenvolden, K. A., and McMenamin, M. A., 1980. Hydrates of natural gas: a review of their geologic occurrence. U.S. Geol. Surv. Circ., 825:1-9.
Li, Y.-H., and Gregory, S., 1974. Diffusion of ions in sea water and in deep-sea sediments. Geochim. Cosmochim. Acta, 38:703-714.

Li, Y.-H., Takahashi, T., and Broecker, W. S., 1969. Degree of saturation of calcium carbonate in the oceans. J. Geophys. Res., 75:5507-5525.

Miura, Y., Rucklidge, J. C., and Nord, G. L., Jr., 1981. The occurrence of chlorine in serpentine minerals. Contrib. Mineral. Petrol., 76:17-23.

Moore, G. W., and Gieskes, J. M., 1980. Interaction between sediment and interstitial water near the Japan Trench, Leg 57, Deep Sea Drilling Project. In von Huene, R., Nasu, N., et al., Init. Repts. DSDP, 56, 57 (Pt. 2): Washington (U.S. Govt. Printing Office), 1269-1275.

Peacock, S. M., 1990. Fluid processes in subduction zones. Science, 248:329-337.

Poty, B., Holland, H. D., and Borcsik, M., 1972. Solution-mineral equilibria in the system $\mathrm{MgO}-\mathrm{SiO}_{2}-\mathrm{H}_{2} \mathrm{O}-\mathrm{MgCl}_{2}$ at $500^{\circ} \mathrm{C}$ and 1 kbar. Geochim. Cosmochim. Acta, 36:1101-1113.

Ritger, S., Carson, B., and Suess, E., 1987. Methane-derived authigenic carbonates formed by subduction-induced pore water expulsion along the Oregon/Washington margin. Geol. Soc. Am. Bull., 48:147-156.

Rucklidge, J. C., 1972. Chlorine in partially serpentinized dunite. Econ. Geol., 67:38-40.

Rucklidge, J. C., and Patterson, G. C., 1977. The role of chlorine in serpentinization. Contrib. Mineral. Petrol., 65:39-44.

Shipboard Scientific Party, 1988a. Introduction, objectives, and principal results, Leg 112, Peru continental margin. In Suess, E., von Huene, R., et al., Proc. ODP, Init. Repts., 112: College Station, TX (Ocean Drilling Program), 5-24.

1988b. Synthesis of shipboard results: Leg 110 transect of the northern Barbados Ridge. In Mascle, A., Moore, J. C., et al., Proc. ODP, Init. Repts., 110: College Station, TX (Ocean Drilling Program), 577-591. , 1990a. Explanatory Notes. In Fryer, P., Pearce, J. A., Stokking, L. B., et al., Proc. ODP, Init. Repts., 125: College Station, TX (Ocean Drilling Program), 15-40.

, 1990b. Site 778. In Fryer, P., Pearce, J. A., Stokking, L. B., et al., Proc. ODP, Init. Repts., 125: College Station, TX (Ocean Drilling Program), 97-114.

1990c. Site 779. In Fryer, P., Pearce, J. A., Stokking, L. B., et al., Proc. ODP, Init. Repts., 125: College Station, TX (Ocean Drilling Program), 114-145.

, 1990d. Site 780. In Fryer, P., Pearce, J. A., Stokking, L. B., et al., Proc. ODP, Init. Repts., 125: College Station, TX (Ocean Drilling Program), 147-178.

1990e. Site 783. In Fryer, P., Pearce, J. A., Stokking, L. B., et al., Proc. ODP, Init. Repts., 125: College Station, TX (Ocean Drilling Program), 253-272.

1990f. Site 784. In Fryer, P., Pearce, J. A., Stokking, L. B., et al., Proc. ODP, Init. Repts., 125: College Station, TX (Ocean Drilling Program), 273-305.

Suess, E., von Huene, R., and the Leg 112 Shipboard Scientists, 1988. Ocean Drilling Program Leg 112, Peru continental margin: Part 2, Sedimentary history and diagenesis in a coastal upwelling environment. Geology, 16:939-943.

von Huene, R., and Lee, H. J., 1983. The possible significance of pore fluid pressures in subduction zones. AAPG Mem., 34:781-791,

\footnotetext{
Date of initial receipt: 2 October 1990

Date of acceptance: 11 September 1991

Ms 125B-121
} 